\title{
Major- and trace-element data and radiogenic isotopes document key features of the Spor Mountain Formation: Host of the largest volcanogenic beryllium resource in the world
}

\author{
ROBERT A. AYUSO AND NORA K. FOLEY
}

United States Geological Survey

Presenting Author: rayuso@usgs.gov

New major, trace-element, and $\mathrm{Pb}-\mathrm{Nd}-\mathrm{Sr}$ isotope data from $\sim 120$ stratigraphically distributed samples of the Spor Mountain Formation (SMF), Utah, were analyzed to trace the evolution of the magma-generating source region. The SMF hosts the largest known deposit of volcanogenic beryllium. The deposit occurs in an area characterized by extensive alkalic rhyolitic ash flow tuffs and Oligocene to Eocene calderas underlain by Paleozoic and older sedimentary rocks. Hydrothermally-altered Be-rich tuff and overlying topaz-rich rhyolite of SMF sampled at the mine have overlapping zircon crystallization ages (SHRIMP U-Pb age ca. $25.6 \mathrm{Ma}$ ). Results show: 1) Be tuff and rhyolite are geochemically similar and magmatically evolved (relatively depleted in $\mathrm{Ba}, \mathrm{Sr}, \mathrm{P}, \mathrm{Zr}, \mathrm{Eu}, \mathrm{Ti}) ; 2$ ) both are alkalic $(\mathrm{Nb} / \mathrm{Y} \sim 0.8$ 3 ), characterized by low ratios of $\mathrm{Nb} / \mathrm{Ta}$, and have overlapping chondrite-normalized REE patterns with large negative $\mathrm{Eu}$ anomalies; 3) mantle-normalized patterns show prominent positive anomalies for $\mathrm{Pb}$ and enrichment in $\mathrm{U}$; 4) SMF has $\mathrm{e}_{\mathrm{Nd}}$ (ca. -7 to -11 ) and ${ }^{207} \mathrm{~Pb} /{ }^{204} \mathrm{~Pb}(>15.60)$ values indicating an upper crustal contribution and/or involvement of enriched mantle (EMII); 5) $\mathrm{Pb}$ isotopic ratios $\left({ }^{206} \mathrm{~Pb} /{ }^{204} \mathrm{~Pb} \sim 18.70-19.00\right.$; $\left.{ }^{207} \mathrm{~Pb} /{ }^{204} \mathrm{~Pb} \sim 15.60-15.80 ;{ }^{208} \mathrm{~Pb} /{ }^{204} \mathrm{~Pb} \sim 39.15-39.80\right)$ do not match isochron slopes, initial isotopic values, and basement ages for nearby mining districts in Utah (e.g., Tintic, Milford); and 6) SMF $\mathrm{T}_{\mathrm{DM}}$ values ( $\mathrm{Nd}$ crustal formation ages) range from $\sim 1.9$ to $2.9 \mathrm{Ga}$.

The SMF is in an area where distinct basement terranes are separated by a suture zone. South of the suture, $\mathrm{T}_{\mathrm{DM}}$ values are 1.8-2.0 Ga (Proterozoic); and north of the suture, $\mathrm{T}_{\mathrm{DM}}$ values are 2.2-3.0 Ga (Proterozoic to Archean) $[1,2] . \mathrm{T}_{\mathrm{DM}}$ values of the SMF overlap values for Proterozoic and Archean basements. The influence of basement terranes may represent a factor for recognizing prospective areas for volcanogenic-hydrothermal Be. The SMF is near or at the transition from the Great Basin (to the west, thinned crust) to the Colorado Plateau (to the east, thicker crust). Thus, we suggest that crustal thickness is another crucial geological attribute associated with world-class deposits of the Spor Mountain type.

[1] Rodriguez and Williams, 2008, Geosph. 4, 315. [2] Wannamaker et al., 2009, Utah Geol. Assoc. Pub. 30. 